\title{
Factor Analysis of Serovars Belonging to Serogroup Holland of Leptospira biflexa
}

\author{
MARINA CINCO AND RITA DOUGAN \\ Institute of Microbiology, University of Trieste, Trieste, Italy
}

\begin{abstract}
Antigenic analysis of serovars belonging to saprophytic serogroup holland of Leptospira biflexa has revealed that both strain WazHolland and strain AM6 contain group-specific antigens and that either can be used as representative of serogroup holland in a preliminary classification of new saprophytic strains.
\end{abstract}

As part of our program to describe the main antigens of the serovars of the saprophytic leptospirae, we present here the results of an antigenic analysis carried out on six serovars, namely holland, lucaia, roma, acquamarcia, piatan, and tredici of serogroup holland $(3,7)$. The following strains, respectively representing the above-mentioned serovars, were used: WazHolland, Lucaia, AM6, AM20, Piatan, and AM13. Strains AM20, AM13, and WazHolland were previously considered, on the basis of antigenic analysis, to be members of the doberdo and aurisina serogroups. The presently reported study is of particular interest because the holland serogroup is composed of a number of serovars which frequently cross-react with newly isolated strains of Leptospira.

\section{MATERIALS AND METHODS}

Bacterial strains. Strain WazHolland of serovar holland was isolated by Bessemans and Thiry (2) and was classified by Castellani et al. (3) in 1970. Strains Piatan and Lucaia were isolated from surface water in Brazil and were classified by Silva (7) as members of serovars piatan and lucaia, respectively. Strains AM6, AM20, and AM13 were isolated by Babudieri and Archetti (1) from drinking water and were classified by Castellani-Pastoris et al. (3) as members of serovars roma, acquamarcia, and tredici, respectively.

Immune sera and serological tests. The preparation of immune sera and the serological procedures used in this study were previously described (5).

\section{RESULTS AND DISCUSSION}

The antigenic compositions determined for the serovars examined in this study are pre- sented in Table 1. Following the nomenclatural system adopted in previous papers $(5,6)$, we used the prefix Ho when referring to the various factors. Thus, factors Ho7, Ho8, Ho9, and $\mathrm{HolO}$ are all detectable on strains WazHolland, AM6, and Piatan, which consequently seem to be closely related and to form a distinct group characterized by the presence of these antigens. Factor Hol0 is also present on strain Lucaia, which, besides this main antigen, has Holl in common with WazHolland. Factor Ho9 is also present on strain AM13, which explains the antigenic relationship between this strain and WazHolland, Piatan, and AM6. However, factor Ho9 is not immunogenic on strain AM13. Strain AM6 seems to have one factor more in common with strain AM13, namely Ho12. Strain AM20, which in a previous study (6) was found to have the main antigens Dob6 and Dob7 in common with members of serogroup doberdò, showed only one main antigen, $\mathrm{Ho}$, in common with the holland serogroup. Consequently, it is considered to be a strain which belongs to both serogroups. An analogous situation was found in the case of strain Farneti, which possesses one main antigen in common with strain Aurisina but a number of minor antigens in common with members of serogroup doberdò.

Factors Hol, Ho2, Ho3, Ho5, and $\mathrm{Ho} 6$ are the serovar-specific antigens of strains Holland, AM6, Piatan, Lucaia, AM13, and AM20, respectively.

Minor factors, reported in Table 2, complete the antigenic patterns of the strains examined. In this table are reported the major and minor

TABLE 1. Antigenic composition of serovars of the leptospiral serogroup holland

\begin{tabular}{|c|c|c|c|}
\hline Serovar & $\begin{array}{l}\text { Reference } \\
\text { strain }\end{array}$ & Major antigens & Minor antigens \\
\hline $\begin{array}{l}\text { holland } \\
\text { roma } \\
\text { piatan } \\
\text { lucaia } \\
\text { tredici } \\
\text { acquamarcia }\end{array}$ & $\begin{array}{l}\text { WazHolland } \\
\text { AM6 } \\
\text { Piatan } \\
\text { Lucaia } \\
\text { AM13 } \\
\text { AM20 }\end{array}$ & 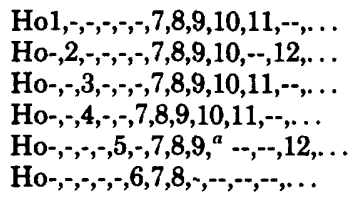 & 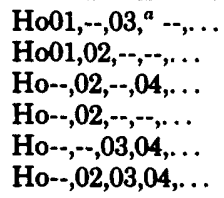 \\
\hline
\end{tabular}

${ }^{a}$ Haptene-like factors. 
TABLE 2. Antigens of holland serovars common to members of other serogroups

\begin{tabular}{|c|c|c|c|}
\hline Serovar & $\begin{array}{c}\text { Reference } \\
\text { strain }\end{array}$ & $\begin{array}{c}\text { Main } \\
\text { antigens }\end{array}$ & Minor antigens \\
\hline $\begin{array}{l}\text { holland } \\
\text { acquamarcia } \\
\text { tredici }\end{array}$ & $\begin{array}{l}\text { WazHolland } \\
\text { AM20 } \\
\text { AM13 }\end{array}$ & Dob6,7, & 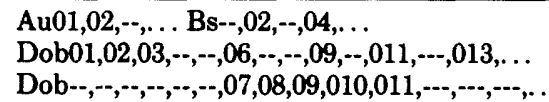 \\
\hline
\end{tabular}

factors of some strains which were included in previous studies and which are responsible for the agglutination of serovars belonging to other serogroups $(4,6)$. From a practical point of view, when the classification of a new isolate is undertaken, immune sera directed against WazHolland and AM6 can be used, for these two strains contain antigens which are representative of serogroup holland of $L$. biflexa.

\section{REPRINT REQUESTS}

Address reprint requests to: Dr. Marina Cinco, Institute of Microbiology, University of Trieste, Trieste, Italy.

\section{LITERATURE CITED}

1. Babudieri, B., and I. Archetti. 1974. Le leptospire acquicole e la loro costituzione antigenica. Rend. Ist. Super. Sanità. Ital. Ed. 10:962-980.
2. Bessemans, A., and U. Thiry. 1928. Presence, dans 'leau de distribution de la ville de gand, d'un leptospire pseudo-icterogene pathogene pour la souris. C. R. Soc. Biol. 99:1881-1883.

3. Castellani-Pastoris, B., B. Babudieri, and E. Polster. 1970. Studio sistematico di alcuni ceppi di leptospire acquicole. Ann. Ist. Super. Sanità 6:270-279.

4. Cinco, M. 1977. Factor analysis of serogroup Botanica and Aurisina of Leptospira biflexa. Zentralbl. Bakteriol. Parasitenkd. Infektionskr. Hyg. Abt. 1 Orig. Reihe A 239:397-402.

5. Cinco, M., and R. Dougan. 1975. Factor analysis of saprophytic serogroups Semaranga and Andamana of Leptospira biflexa. Int. J. Syst. Bacteriol. 25:138142.

6. Cinco, M., R. Dougan, and I. Stefanelli. 1977. Factor analysis of saprophytic serogroup Doberdo of Lepto. spira biflexa and characterization of serovars 200 and drahovce. Int. J. Syst. Bacteriol. 27:63-65.

7. Silva, I. 1974. Studio sistematico di leptospire saprofite isolate in Brasile. Ann. Ist. Super. Sanità 10:21-25. 